\title{
Disclosure of innovation activities by high-technology firms
}

\author{
Feng $\mathrm{Gu}^{\mathrm{a*t}}$ and John Q. $\mathrm{Li}^{\mathrm{bt}}$ \\ "Boston University \\ ${ }^{b}$ Suffolk University
}

Received September 2002; Accépted April 2003

\begin{abstract}
This study investigates management incentive to disclose non-GAAP indicators concerning innovation in high-technology industries and the usefulness of the disclosure. As predicted, we find that firms increase disclosures of innovation when current earnings are less informative, or when future earnings are more uncertain. This finding is consistent with firms increasing disclosure in response to investor information demands when accounting data are less useful in assessing firm value. We also find that disclosures of innovation contain price-sensitive news. In addition, we find that disclosures of innovation are positively associated with the firm's future sales growth, profitability, and stock returns, after controlling for current performance and other factors known to influence future performance. This evidence is consistent with management disclosure conveying valuerelevant information that is not reflected in current performance, but is predictive of future performance. (1) City University of Hong Kong.
\end{abstract}

JEL Classification: $M 41$ and 031

Keywords: disclosure; innovation; value-relevance; high-technology

\section{Introduction}

Recent studies on intangible assets tend to focus on accounting information reported in financial statements (e.g. R\&D expenditures). However, there has been little research on

\footnotetext{
"Correspondence to Professor Feng Gu, Boston University, School of Management, 595 Commonwealth Avenue, Boston, MA 02215. Tel: (617) 353-4985; E-mail: gu@bu.edu.

' We are grateful for insightful comments from Linda Bamber. Christine Botosan, Nick Dopuch, Bob Elliott, Pat Hopkins, James Largay, Baruch Lev, and Krish Menon. We would also like to thank participants at the American Accounting Association 2003 Financial Accounting and Reporting Section Mid-Year Meeting, the APJAE 2003 Symposium for their helpful suggestions and in particular those of Chul W. Park. Feng Gu is thankful for the financial support provided by Boston University School of Management. John Q. Li acknowledges the support of the Faculiy Research Grant at Lehigh University.
} 
management disclosure of qualitative or non-financial information about intangibles. This study examines management disclosure of indicators concerning innovation that lie outside the confines of the generally accepted accounting principles ("GAAP"). We investigate management incentive to provide disclosure about the key elements of innovation. We also provide evidence on the usefulness of the disclosure.

We predict that firms have greater incentives to make disclosures about innovative activities when earnings are less useful in reflecting the value and performance of intangible assets. Earnings are expected to be less useful when current earnings are less informative, or when future earnings are more uncertain. Under these conditions, disclosures of value-relevant information - such as indicators of innovation - are likely to be useful to investors. We hypothesize that disclosures of innovation are greater when reported earnings are less informative due to the joint effect of immediate expensing of $R \& D$ and increases in the rate of $R \& D$ spending. We also predict greater disclosures for firms with higher R\&D intensity, firms reporting losses, younger firms, and firms with more volatile stock returns, as these firms tend to have more uncertain future earnings. Consistent with management incentive to supplement current earnings with value-relevant information, we further hypothesize that disclosures of innovation reveal information that is not reflected in the firm's current performance, but is relevant for future performance.

Consistent with this set of predictions, we find that firms make greater disclosures of innovation when they increase the rate of R\&D spending. We also find that disclosures of innovation are positively associated with the firm's R\&D intensity, indicator of losses, and stock return volatility, and are negatively associated with the firm's age. Our findings remain significant after controlling for the size of $R \& D$ activities and factors that prior studies show are associated with disclosure decisions, such as firms' access to capital markets, industry membership, firm size, and growth prospects (e.g. Frankel et al. (1995), Lang and Lundholm (1993)). This evidence is consistent with firms increasing disclosure in response to demands by investors for information when financial accounting data are less useful to investors as they attempt to assess firm value. We also find that disclosures of innovation are positively associated with stock returns, suggesting that the disclosure is informative. In addition, we find that disclosures of innovation are positively associated with a firm's future sales growth rate, profitability, and stock returns. This result remains statistically significant and economically meaningful after controlling for current performance and other factors known to influence future performance. Our evidence is consistent with management disclosures conveying to investors value-relevant information that is not reflected in current performance, but that is predictive of future performance.

This study contributes to the literature that examines management disclosures and the usefulness of information on intangible assets. While prior empirical studies find that accounting information on investments in intangibles is value-relevant, little research exists on firms 'incentives to disclose non-GAAP indicators relating to intangibles. We shed light on this issue by examining media disclosures of innovation activities by 140 high-technology firms. Our results indicate that disclosures of innovation are inversely related to the informativeness of current earnings and are positively associated with the uncertainty in future earnings. This evidence is consistent with the findings of recent studies that firms increase their level of disclosure when investors demand additional value-relevant information to help assess firm value (e.g. Chen et al. (2002), Tasker 
(1998)). Moreover, our evidence suggests an association between disclosures of innovation and the firm's future economic performance, which corroborates the result of Lundholm and Myers (2002) that management disclosures convey information related to future earnings.

The remainder of this paper proceeds as follows. Section 2 motivates our hypotheses. Section 3 describes the disclosure metric used in this study. In section 4 , we explain the research design of the study, including the statistical model and estimation of empirical proxies. Section 5 describes the sample and reports empirical results. Section 6 provides a summary and conclusions.

\section{Hypothesis development}

\subsection{Dêterminants of disclosures of innovation}

Prior research suggests that firms have incentives to disclose information that is useful to investors in assessing firm value (Grossman (1981), Dye (1985)). We expect that managers have greater incentives to disclose non-financial information when financial information, such as earnings, is less useful. In the setting of high-technology industries, disclosures of innovation are likely to be useful to investors because financial information based on traditional accounting models does not adequately reflect the value created by innovative activities such as R\&D (FASB (2001a), SEC (2001)). When earnings are less useful, it is likely that disclosures of innovation, particularly those concerning the firm's long-term strategies or non-financial leading indicators, can provide investors with more value-relevant information. Consistent with Chen et al. (2002), we expect earnings to be less useful in valuing firms when current earnings are less informative, or when future earnings are more uncertain. Thus, our overall prediction is that high-technology firms make more disclosures of innovation when current earnings are less informative, or when future earnings are more uncertain.

From an accounting measurement perspective, the lack of informativeness in earnings of high-technology firms is likely related to a mismatch between revenues and expenses under the expensing rule of R\&D. When the investment rate in R\&D changes over time, reported earnings based on immediate expensing will differ materially from economic earnings based on capitalisation of R\&D. This distortion in the accounting measurement process is expected to adversely affect the usefulness of earnings information. Consistent with this, Lev and Zarowin (1999) find that firms with greater increases in the rate of $R \& D$ spending have less informative earnings, as indicated by lower earnings response coefficients and smaller $R^{2} \mathrm{~s}$ in the return-earnings regression. Thus, we predict a positive association between disclosure of innovation and change in R\&D spending rate. This is our first hypothesis (in alternate form):

$\mathrm{H}_{1}$ : Firms with higher increases in the R\&D spending rate make more disclosures of innovation.

Firms in high-technology industries also operate in highly uncertain business environments, largely due to uncertain future outcomes from investments in innovation. Compared 
to other corporate activities such as production and marketing, innovation is highly risky and thus increases the uncertainty in future earnings. Consistent with this, Kothari et al. (2002) find that future earnings volatility associated with $R \& D$ is about three times larger than future earnings volatility associated with investment in physical assets. The inherent risk makes the disclosure of innovation - such as the nature and progress of the activity relatively more useful to investors as they assess the potential payoff of the investment.' Hence, our second hypothesis is (in alternate form):

$\mathrm{H}_{2}$ : Firms with higher R\&D intensity make more disclosures of innovation.

We also expect high-tech firms to increase disclosure of innovation when they report losses. Since negative earnings are less useful for valuing firms (Collins et al. (1997), Hayn (1995)), investors are likely to have greater demand for additional value-relevant information to supplement the information in earnings in the event of losses. Moreover, for R\&D-intensive firms, losses are often indicative of the absence of revenue during early stages of the innovation process. Given early-stage innovations tend to be associated with more uncertain prospects, and hence more uncertain future earnings, disclosures of innovation are likely to be more useful to investors for assessing the value of such firms. ${ }^{2}$ Thus, we expect firms to have greater incentives to make disclosures about their innovation activities when they experience losses. This is our third hypothesis (in alternate form):

$\mathrm{H}_{3}$ : Firms reporting operating losses make more disclosures of innovation.

Firm age may also affect investors' demand for value-relevant information. Lang (1991) suggests that investors are inclined to find disclosure of younger firms more useful, because future operations of younger firms are likely to be less predictable and there is more uncertainty about the earnings prospects for such firms. Consistent with this, Chen et al. (2002) find that younger firms are more likely to make voluntary disclosure of quarterly balance sheet information. Thus, we predict that younger firms make more disclosures of innovation. ${ }^{3}$ This is our fourth hypothesis (in alternate form):

$\mathrm{H}_{4}$ : Younger firms make more disclosures about their innovative activities.

\footnotetext{
( $R \& D$ intensity may also proxy for information asymmetry between managers and investors. Aboody and Lev (2000) find that the frequency and gain of insider trading are greater for firms with higher R\&D intensity, suggesting that $R \& D$ is a major contributor to information asymmetry. Prior studies suggest that firms with greater information asymmetries are more likely to make disclosures (e.g. King et al., 1990). Thus, the information asymmetry hypothesis also predicts a positive association between disclosure and R\&D intensity.

${ }^{2}$ The decreasing risk along the innovation path was documented in Mansfield and Wagner (1977). In a study of R\&D projects in 16 companies. they estimated that the improvement in the mean probabilities of success was about $8-9 \%$ as products moved toward later stages of innovation.

"Younger firms tend to have greater information asymmetry, as they are typically followed by fewer analysts. Therefore, the information asymmetry hypothesis (e.g. King et al. (1990)) also predicts that younger firms make more disclosures.
} 
Investors' demand for information about innovation of high-technology companies is also likely to be associated with stock return volatility. Higher stock return volatility suggests greater uncertainty about future earnings, as stock prices reflect investor expectations of future earnings. Disclosures are likely more useful to investors when facing more uncertainty in future earnings; therefore, we expect that firms with more volatile stock returns make more disclosures of innovation. Thus, our fifth hypothesis is (in alternate form):

$\mathrm{H}_{5}$ : Firms with higher stock return volatility make more disclosures of innovation.

\subsection{Proprietary costs, litigation costs, and disclosures of innovation}

A firm's disclosure is likely to be affected by proprietary information costs (Verrecchia, 1983). We expect proprietary costs to increase as firms invest more in innovation, due to the fuzziness of property rights of most intangibles and the difficulty of appropriating benefits from such assets. The proprietary costs hypothesis, therefore, predicts that firms investing more in innovation are less likely to provide disclosure. This is opposite to our prediction that firms with higher $R \& D$ intensity make more disclosures. Thus, proprietary information costs should operate against finding the result predicted by Hypothesis 2 . Moreover, prior studies suggest that proprietary costs vary by industry competitiveness (Harris (1998), Clarkson et al. (1994)), which is captured by an industry dummy in our regression analysis.

Litigation costs may also affect firms' disclosure decisions. Litigation against firms for omitted or untimely disclosures can motivate managers to increase disclosure; however, the threat of litigation may also reduce firms' incentives to provide disclosure, if disclosures can be cited as a precipitating factor in litigation. Empirical evidence on the relation between disclosure and litigation costs is mixed. Skinner (1994) finds that firms are more likely to pre-disclose earnings in anticipation of adverse earnings news, whereas Francis et al. (1994) find no evidence that disclosures are effective in deterring litigation. Research also finds that litigation costs are higher in high-technology industries (e.g. Jones and Weingram, 1996). As described in section 5, we restrict our sample to high-technology firms, thus mitigating cross-sectional variations in litigation costs associated with industry membership.

\subsection{Usefulness of disclosures of innovation}

Prior studies find a positive contemporaneous relationship between firm value and accounting information on intangible assets, indicating that these measures are useful to investors. ${ }^{4}$ Consistent with these results, we expect disclosures of non-GAAP indicators concerning innovation to be informative. Furthermore, consistent with management incentive to supplement earnings information with disclosures of innovation, we also hypothesize that these disclosures contain value-relevant information on leading indicators that are not yet reflected in the firm's current financial statements, but are predictive

\footnotetext{
${ }^{4}$ For a summary of these studies, see Lev (2001, Ch. 4).
} 
of the firm's future performance. Therefore, we predict a positive association between disclosures of innovation and the firm's future performance. This is consistent with the finding of Lundholm and Myers (2002) that management disclosures convey to investors information that is not in the firm's current earnings but that is relevant for its future earnings. Hence, our sixth and seventh hypotheses are (in alternate form), respectively:

$\mathrm{H}_{6}$ : Disclosures of innovation are associated with significant contemporaneous market reactions.

$\mathrm{H}_{7}$ : Disclosures of innovation are positively associated with the firm's future economic performance.

\section{Disclosure metric}

We base our measure of disclosure level on information firms provide in their media news releases. Compared to annual reports, news media allows companies to disseminate information in a timelier manner. Timely information is more useful to investors because of the ever-changing nature of innovation. We also expect media disclosure to be a good proxy for the overall level of disclosure across all information avenues, as prior studies suggest that the levels of disclosure provided by firms via different media are positively correlated (Lang and Lundholm, 1993). The database of media disclosure used in this study is NEXIS/News/Wires provided by the NEXIS Academic Universe.

To measure the quantity of disclosure, we construct a metric based on the amount of news reported by companies about innovation. This metric consists of only generic information items that are applicable to all firms, regardless of their differences in size, industry membership, and other characteristics. The selection of items included in the metric was guided by economic studies of innovation and recent recommendations on improving business reporting made by special committees of the Financial Accounting Standards Board ("FASB") and the Securities and Exchange Commission ("SEC") (FASB (2001b), SEC (2001)). A common belief in the committees' recommendations is that investors will benefit from more disclosures about intangible assets. ${ }^{5}$ Accordingly, we choose items suggested by prior studies as relevant to investors in assessing the nature, risk, and potential payoffs of innovation. We summarise these items into three information categories: strategy, progress, and completion or commercialisation. Exhibit 1 provides a list of information items used in the construction of our disclosure metric. Also included in the Exhibit are sample disclosures for each information item.

\footnotetext{
The FASB's Steering Committee Report states: "Disclosure of information about unrecognized intangible assets such as research and development, human resources, customer relations, innovations, and others that are critical to the success of a business would be especially helpful to investors in making investment decisions" (FASB, 2001b). Similarly, the report of the SEC-inspired task force concludes: "The task force believes that improved supplemental disclosures of intangible assets and operating performance measures would provide significunt benefits to investors valuing dynamic, high-growth companies" (SEC, 2001).
} 
Exhibit 1

Summary of Key Information Items of Disclosure About Corporate Innovation

Description of Information Item Example of Firm Disclosure

A.Information About Strategy Relating to Innovation

1. Articulation, explanation, and discussion of strategy

2. Nature of innovation (e.g. basic research. process and product development)

3. Goal. objective, or plan of innovation

4. Relation with current innovation (e.g. strategic new initiative, enhancement of existing technology)

5. Time frame (e.g. years to complete)

6. Amount of financing or spending planned

7. Form of R\&D venture $(e, g$, alliance with other firms, contracting with government or other firms)

8. Acquisition of other firms for new technology or other innovation capabilities

\section{B. Information About Progress of Innovation}

9. Breakthrough or milestone of research and development (e.g. patent award, FDA approval, internal testing, and indication of technology leadership in industry)
"SyntroVet's strategy for further development of its swine vaccine line is to focus on diseases of major economic significance to the sophisticated pork producer," (Syntro Corp, 93/10/05)

"With this new agreement, we will be working even more closely together to develop the process technology advancements required to meet our customers' everincreasing need for device performance and density enhancements." (Lattice Semiconductor Corp., 94/05/16)

"Somatix will develop and supply a genetically modified cell line designed to over-produce the human blood clotting proteins factor VIII or factor IX." (Somatix Therapy Corp.. 93/11/(03)

"InterVoice, Inc, today announced plans to significantly enhance its automated call processing platform's application development user interface." (InterVoice, Inc.. 94/08/19)

"The study is designed to complement the already ongoing clinical trial, and is expected to be completed in the second quarter of 1994." (Lmmulogic Pharmaceutical Corp., 93/11/03)

"An up-front budget of $\$ 100,000$ has been reserved for the joint research and development of the above mentioned projects." (LaserSight Inc., 93/02/04)

"Irvine Sensors Corp. announced today the receipt of an approximate $\$ 5.2$ million contract to develop a neural network sensor. The new 26-month contract is being funded by the Strategic Defense Initiative Oftice." (Irvine Sensors Corp. 92/04/13)

"Kulicke \& Soffa Industries Inc. Thursday announced that it has acquired the assets and technology of Assembly Technologies, a division of General Signal, for an undisclosed amount of cash." (Kulicke \& Soffa Industries Inc., 94/07/14)

"HealthWatch Inc, today announced that it has received permission to market its Universal IV Controller from the U.S. Food and Drug Administration." (HealthWatch Inc., 94/ 04/05)

"MicroProse Software, Inc, today announced a breakthrough at the intersection of computer science and the arts. The program composes and performs original high-quality music in real time, using mathematical algorithms, inspired by classical composers like Johann Sebastian Bach." (MicroProse Software. Inc.. 93/05/28) 
Exhibit 1 (Cont.)

Summary of Key Information Items of Disclosure about Innovation

\begin{tabular}{|c|c|}
\hline Description of Information Item & Example of Firm Disclosure \\
\hline \multicolumn{2}{|l|}{ B. Information About Progress of Innovation } \\
\hline $\begin{array}{l}\text { 10. Details of pipeline projects or new products } \\
\text { under development }\end{array}$ & $\begin{array}{l}\text { "During the first half of } 1992 \text { we expect to introduce two } \\
\text { advanced coprocessor based Super VGA controllers. Initial } \\
\text { customer response to these products has been highly } \\
\text { favorable." (Tseng Labs, Inc., } 92 / 02 / 20 \text { ) }\end{array}$ \\
\hline $\begin{array}{l}\text { 1I. Human capital (e,g. Iurnover of star } \\
\text { scientists and details on research teams) }\end{array}$ & $\begin{array}{l}\text { "ImmunoPharmaceutics Thursday announced that } \\
\text { internationally known pharmaceutical biotechnologist, De. } \\
\text { Seymour Mong, bas joined the company as Vice President } \\
\text { for Biotechnology." (Synbiotics Corp. 92/04/23) }\end{array}$ \\
\hline $\begin{array}{l}\text { 12. Implementation, continuation, or termination } \\
\text { of R\&D projects }\end{array}$ & $\begin{array}{l}\text { "Also, the company is continuing its investment in the } 1.8 \\
\text { inch form factor and is reducing its investment in the } 21 / 2 \\
\text { inch form factor since the smaller } 1.8 \text { inch form factor is } \\
\text { more attractive for mobile computer applications." (SyQuest } \\
\text { Technology Inc., 93/07/15) }\end{array}$ \\
\hline 13. Continuation of available financing & $\begin{array}{l}\text { "With products being developed for cancer, septic shock and } \\
\text { organ reperfusion injury, this strong capital infusion will } \\
\text { allow aggressive pursuit of the clinical testing necessary to } \\
\text { provide data to support license applications to market our } \\
\text { products." (Ribi ImmunoChem Research Inc., 92/04/02) }\end{array}$ \\
\hline $\begin{array}{l}\text { 14. Indication of whether } R \& D \text { projects are on } \\
\text { schedule }\end{array}$ & $\begin{array}{l}\text { "Development work on several automated systems is } \\
\text { behind schedule, but the company anticipates second half } \\
\text { sales of its new automated packaging and quality control } \\
\text { products." (Innovex, Inc., 92/04/23) }\end{array}$ \\
\hline
\end{tabular}

\section{Information About Completion or Commercialisation of Innovation}

15. New product launch or acceptance by market

16. Patent licensing and royalty

17. Transfer or sale of technology or patent

18. Marketing alliance for new products

19. Litigation concerning intellectual properties (e,g. patent infringement and breach of licensing agreements) "lomega Corporation Monday announced the Bernoulli 230 drive and 230 megabyte cartridge." (Iomega Corporation. $94 / 09 / 26$

"Intersolv Inc. announced that Informix has licensed Intersolv's DataDirect ODBC Drivers for inclusion in its development and end-user access tools." (Intersolv Inc., 94/ $09 / 12$ )

"Melamine Chemicals lnc. Thursday announced the sale of its controlled-release fertilizer technology." (Melamine Chemicals Inc., 94/03/31)

"AT\&T Network Systems and Tekelec announced today that they have signed an agreement under which AT\&T will distribute Tekelec's EAGLE ( $r$ ) STP product." (Tekelec, 94/ $09 / 19$ )

"PSC Inc, announced today that it has filed two patent infringement lawsuits against Spectra-Physics Scanning Systems, Inc. for its SP300 and SP400 models and against Metrologic Instruments, Inc. for its 900 Series, respectively." (PSC Inc., 92/07/01) 


\subsection{Strategy}

Information on firms' strategies provides investors with the necessary background to assess inherent business risk and the likelihood of future success. In its framework for providing voluntary disclosures, the FASB's Steering Committee Report specifically identifies, among other elements, "management's strategies and plans for managing those critical success factors in the past and going forward" (FASB, 2001b). The importance of the process and high risk of innovation means that information on strategies for developing and discovering intangible assets should be especially useful to investors. The disclosure items in this category include details on the strategic elements of innovation, focusing on the planning and organisations for the activity. Of particular importance are management's articulation and explanation about the goals and nature of innovation (e.g. basic research versus applied research) and how innovation is carried out - forms of alliance and means of acquisition.

\subsection{Progress}

Indicators on the progress of innovation are particularly useful to investors because they contain timely information that is typically omitted in financial reports. Thus, the SEC-inspired task force concluded, "they [investors] also need to understand the key milestones for the development of the company and its progress on achieving key operating performance measures" (SEC, 2001). The disclosure measure in this category includes information on the developments or achievements of innovation, which should help investors to assess the output of innovation and the change in risk concerning innovation as the process moves along.

Items in this category reflect specific indicators as well as general information about the progress of innovation. Information on R\&D breakthroughs or milestones, such as successful product testing and clinical trials, award of patents, and FDA approval of new drugs, indicates specifically measurable progress of companies' innovation activities. ${ }^{6}$ Details of pipeline projects or new products under development provide early indication of such progress. We also include in the metric information on human factors such as the turnover of star scientists and details on the experience of research teams, because human capital is indispensable to innovation.? Disclosure of general information about the innovation process, including the status of R\&D projects, availability of future financing, and whether project development is on schedule, may also provide useful updates for investors.

\subsection{Completion or commercialisation}

Eventual completion and commercialisation signifies the success of innovation, and information on the delivery of marketable products or services helps investors assess the

\footnotetext{
${ }^{8}$ Recent studies find that such indicators provide useful information to investors assessing the prospects of R\&D (Ely et al. (2002), Gu and Lev (2002), Shortridge (2000), Bowen and Shores (2000)). For a summary of studies on the usefulness of patent-related measures, see Lev (2001).

'Darby et al. (1999) find that the quality of biotech firms' R\&D personnel, measured by the number of publications and the status of authors, is positively associated with firms' future success and market values.
} 
value created by the activity. In setting international accounting standards, the existence of a market for the output of intangibles arising from development is often a key criterion for the recognition of internally developed intangibles as assets. For instance, the International Accounting Standards IAS 38 specifically identifies the existence of markets for firms' products as a condition for capitalising internally developed intangibles (IASC, 1998). ${ }^{8}$ The items included in this category, therefore, focus on the markets for firms' products and technologies such as new product launches, marketing alliances, and licensing or sale of patents. ${ }^{9}$ The ultimate value of innovation, of course, hinges on the owners' ability to effectively enforce the property rights of intangibles. This is particularly important, because the property rights of most intangibles are not well defined. As such, in the metric we also include information on litigation involving firms' intellectual properties, such as patent infringement and breach of licensing agreements.

\subsection{Calculation of the disclosure score}

Using the disclosure metric outlined above, we computed a disclosure score, which we refer to as DISC, to quantify the amount of media disclosure that firms provide. In calculating the disclosure score, we give equal weight to all information items and assign one point (1.0) to a firm for the disclosure of an item. This scoring procedure was applied to press releases made by sample firms during 1992 to 1994. The disclosure score of a press release was the number of non-redundant information items it contained. ${ }^{10}$ If information items pertaining to the same event appear in multiple press releases, they are counted only once, in the disclosure score of the earliest press release. For each year, we compute a firm-specific disclosure score by summing the number of points across all press releases

\footnotetext{
${ }^{8}$ The other conditions set forth by IAS 38 , such as indicators of technical feasibility and availability of adequate financial resources to complete the development, are reflected in our disclosure metric pertaining to the information category of "Progress".

${ }^{7}$ For evidence on the value-relevance of patent licensing information (e.g. royalties), see Gu and Lev (2002),

${ }^{10}$ The following example illustrates the scoring procedure employed in our study:

"April 12, 1994-Robotic Vision Systems Inc. (RVSI) today announced the award by the United States Federal Aviation Administration (FAA) of a $\$ 460,000$ contract to fund further research and development of RVSI's new ID-1 aircraft ice detection technology. RVSI's proprietary technology detects ice by electro-optical means and can help verify the safe condition of entire aircraft surfaces in a short time. The technology can be adapted to both ground-based and airborne ice detection systems and is expected to have significant safety, economic, and environmental benefits. RVSI's contract was awarded under the FAA's Broad Agency Announcement program. which seeks to fund important innovations in aircraft ice detection technology. Besides performing further in-house research. development, and testing, RVSI will deliver an ice detection system to the FAA for testing and evaluation this year."

Using the disclosure metric displayed in Exhibit 1 , we identify in the announcement four useful information items, namely the form of $R \& D$ venture (a research contract), amount of financing (provided by the contract), the nature of the innovation (research and development of RVSI's ice detection technology), and the objective and plan (delivery of an ice detection system to the FAA for testing and evaluation this year). Accordingly, we assign a disclosure score of 4.0 to this press release.
} 
attributable to the firm." A separate disclosure score is also computed for each information category.

\section{Research design}

To test our hypotheses on the relation between disclosures of innovation and the informativeness of earnings, we estimate the following model:

$$
\begin{aligned}
& \text { DISC }_{i t}=a_{0}+a_{1} \text { RDGW }_{i t}+a_{2} \text { RDINT }_{i t}+a_{3} \text { DLOSS }_{11}+a_{4} A G E_{i l}+a_{5} \text { RETVOL }_{i t}
\end{aligned}
$$

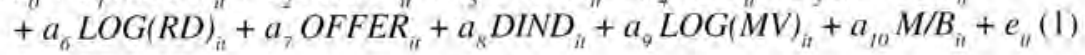

The main variables of interest in the model are RDGW, RDINT, DLOSS, AGE, and RETVOL. These variables are our proxies for the lack of informativeness in current earnings, or uncertainty in future earnings. We predict a positive coefficient on RDGW, RDINT, DLOSS, and RETVOL, and a negative coefficient on AGE.

Control variables in this model follow prior studies on determinants of management disclosure. ${ }^{13}$ Frankel et al. (1995) find that firms make more disclosures before accessing

\footnotetext{
"Given the substantial amount of work involved in interpreting and scoring press releases, the process was shared between the authors. To ensure the consistency in applying the scoring procedure, we constantly checked the coding results of each other and reconciled occasional discrepancies.

${ }^{12}$ We define loss firms as those reporting negative net income before extraordinary items (from Compustat).

17 Although we attempt to control for factors that prior studies suggest are associated with management disclosure, the possibility remains that the model does not include other firm characteristics that might affect disclosures of innovation. Our results are subject to this caveat to the extent that these factors are correlated with our proxies for the lack of informativeness in current earnings, or the uncertainty in future earnings.
} 
the capital market, which is consistent with a negative relation between disclosure and cost of capital (Healy et al. (1999), Sengupta (1998), Botosan (1997)). We thus predict a positive association between disclosures and an indicator of firms filing for debt or equity offering $(O F F E R)$. We also control for cross-industry differences in disclosure practices. Prior studies find that biotech and pharmaceutical firms tend to provide more disclosures than firms from other industries (FASB (200Ib), Cohen (1992)). ${ }^{14}$ To capture this pattern, we use a dummy variable (DIND) that equals 1 for firms with three-digit SIC of 283 and 0 otherwise. We also include in the model the logarithm of market value $(L O G(M V))$ to control for firm size and $M / B$ (market-to-book ratio) to control for growth prospects. Earlier studies find that they are correlated with firms' disclosure decisions as well (e.g. Tasker (1998), Lang and Lundholm (1993)). Lastly, we control for a possible mechanical relationship between the size of the firm's R\&D activities and disclosures of innovation by including in the model the natural logarithm of the firm's R\&D expenditures ( $L O G(R D)$ ).

We perform an event study to investigate whether investors respond to disclosures of innovation by high-technology firms (Hypothesis 6). Specifically, we estimate the following pooled OLS conditional market model: ${ }^{15}$

$$
R_{i, t}=\alpha_{i}+\beta_{i} R_{M, i}+\sum_{k=1}^{10} \lambda_{i, i} \delta_{k, d, t}+\varepsilon_{i, t}
$$

Where:

$R_{i,}=$ the firm's return on day $t$;

$R_{M, t}=$ the return on value-weighted market portfolio on day $t$;

$\delta_{k, i, t}=-1$ (1) if the firm made disclosure containing negative news of innovation (other news) of type $k$ on day $t, 0$ otherwise; and

$k$ = type of disclosure, $k=1, \ldots, 19$, as defined by information items listed in Exhibit 1 .

We also estimate the model using indicator variables for each of the three information categories described in section $3\left(\delta_{k, i, x^{\prime}}, k=\mathrm{A}, \mathrm{B}, \mathrm{C}\right)$. This formulation allows us to assess the average market response to disclosure defined by each of the three information categories (A includes $k=1-8 ; \mathrm{B}$ includes $k=9-14 ; \mathrm{C}$ includes $k=15-19$ ).

Hypothesis 7 predicts that disclosures are positively associated with subsequent firm performance. To test this, we estimate the following models using sales growth and operating margin as measures of firm performance:

$$
\text { SALESGW }_{i+1}=b_{n}+b_{1} \text { SALESGW }_{i t}+b_{2} \text { RDINT }_{i t}+b_{3} \text { CAPITAL }_{i t}+b_{4} \text { DISC }_{i j}+u_{i t}(3)
$$

\footnotetext{
${ }_{14}$ This difference is likely related to the costs and benefits of disclosure. The long product development cycle in biotech and drug industries tends to postpone revenues for many firms and increase the need for external financing, hence the benefits of disclosure. Moreover, proprietary information costs may be lower, since clear delineation of property rights of biotech and drug companies is expected to decrease opportunities for competitors to benefin from disclosure. This seems consistent with the finding of prior studies that biotech and drug companies are far less concerned with competitors benefiting from the substantial disclosures required in patent applications (Cohen et al. (2000), Levin et al. (1987)).

${ }^{15}$ See Francis et al. (1994) for a similar approach and Campbell et al. (1997) for a discussion of the advantage of this appreach for analysing abnormal returns of firms with overlapping event dates.
} 


$$
O P M G_{i t+1}=c_{n}+c_{1} O P M G_{i t}+c_{2} R D I N T_{i t}+c_{3} \text { CAPITAL }_{i t}+c_{4} \text { DISC }_{i t}+v_{i t}
$$

Where:

$S A L E S G W_{i t+1}=$ the firm's sales growth rate of year $t+1$, calculated as the percentage change of sales from year $t$ to year $t+1$;

$S A L E S G W_{i t}=$ sales growth rate of year $\mathrm{t}$, calculated as the percentage change of sales from year $t-1$ to year $t$;

$O P M G_{i t+1}=$ operating margin of year $t+1$, defined as operating income (before advertising expenses and $R \& D$ expenditure) divided by sales of year $t+1$;

$O P M G_{i t} \quad=$ operating margin of year $t$, defined as operating income (before ad vertising expenses and $\mathrm{R} \& \mathrm{D}$ expenditure) divided by sales of year $t$;

$R D I N T_{i r}=\mathrm{R} \& \mathrm{D}$ intensity (the ratio of $\mathrm{R} \& \mathrm{D}$ expenditure to sales);

CAPITAL $_{\text {it }}=$ a dummy variable equal to 1 if the firm accesses the capital market for debt or equity financing in the current fiscal year, and 0 otherwise; and

DISC $_{i t} \quad=$ the disclosure score of year $t_{+}$

The main variable of interest in equations (3) and (4) is DISC, the disclosure score of the current year. We include in the model the lagged values of the dependent variable as control variables because prior studies document that the lagged value of accounting numbers is useful for predicting the future value. ${ }^{16}$ We also control for the positive effect of investment in R\&D (RDINT) and the availability of additional capital (CAPITAL) on the firm's future accounting performance. ${ }^{17}$ In this analysis, we choose not to use earnings as the performance measure because of the bias it contains due to the expensing of R\&D. ${ }^{18}$ If disclosures of innovation contain information that is not already reflected in current performance but is indicative of future performance, we expect the coefficient on the disclosure score (DISC) to be positive ( $b_{4}$ and $c_{t}$ in equations (3) and (4), respectively).

We also assess the association between current disclosures and subsequent stock returns. Compared to accounting information, stock returns are likely to be a more comprehensive and timely measure of firm performance. Specifically, we estimate the following model:

$$
\begin{aligned}
\operatorname{RETURN}_{i t+1}= & d_{0}+d_{i} \text { BETA }_{i t}+d_{2} \operatorname{LOG}(M V)_{i t}+d_{3} \operatorname{LOG}(B V / M V)_{i t} \\
& +d_{i t} \text { LOG }(\text { LEVG })_{i t}+d_{5} E(+) / P_{i t}+d_{6} \operatorname{DLOSS}_{i t}+d_{j} \text { RDINT }_{i t} \\
& +d_{s} \text { CAPITAL }_{i t}+d_{9} \text { DISC }_{i t}+w_{i t}
\end{aligned}
$$

\footnotetext{
${ }^{10}$ For example, Watts and Leftwich (1977) find that past earnings are predictive of future earnings.

${ }^{17}$ The regression model of equation (3) does not incorporate a possible non-linear relation between future sales growth and current sales level. Our results based on this model are, therefore, subject to this limitation.

${ }^{18}$ Conceptually, the problem can be mitigated by capitalising and amortizing R\&D in a manner consistent with the economic useful life of R\&D and then adjusting reported earnings accordingly. However, estimates of useful life and amortization rate at the firm level are likely to be subject to errors.
} 
Where:

RETURN $_{i t+1} \quad=$ the firm's stock returns cumulated from nine months before the end of year $t+1$ to three months after it;

$B E T A_{n}=$ the Capital Asset Pricing Model beta estimated using monthly stock returns over the preceding 60 months;

$L O G\left(M V^{V}\right)_{i r} \quad=$ logarithm of market value at fiscal year-end;

$\operatorname{LOG}(B / M)_{i l} \quad=$ logarithm of the ratio of book value of equity to market value (measured at fiscal year-end);

$L O G(L E V G)_{i t}=$ logarithm of financial leverage, calculated as the ratio of the book value of total assets to the book value of total equity;

$E(+) / P_{i t} \quad=$ earnings before extraordinary items deflated by market value for firms with positive earnings and 0 for firms with negative earnings;

$D_{\text {LOSS }} \quad=$ a dummy variable equal to $\mathrm{I}$ for loss firms and 0 otherwise;

RDINT $_{\text {ir }} \quad=\mathrm{R} \& \mathrm{D}$ intensity (the ratio of R\&D expenditure to sales);

CAPITAL $_{i t} \quad=$ a dummy variable equal to 1 if the firm accesses the capital market for debt or equity financing in the current fiscal year and 0 otherwise; and

$\operatorname{DISC}_{i t} \quad=$ the disclosure score of year $t$.

Equation (5) is based on the model of Fama and French (1992). Besides the variables that have been shown to predict future stock returns (beta, firm size, book-to-market ratio, leverage, and earnings), we include in the model RDINT and CAPITAL as additional control variables. The objective of this regression is to assess whether the information contained in the disclosure score (DISC) is predictive of future returns after controlling for the effect of these other factors.

\section{Sample data and empirical results}

\section{5,1 Sample selection and descriptive statistics}

Subject to the cost constraint of computing the disclosure score, we intended to select a sufficiently large sample of firms that was representative of companies investing in technological innovation, as indicated by the significance of their R\&D expenditure. Our sample selection procedure is summarised in Table 1. From the 1999 Compustat merged annual files, we identified a total of 4,039 firms that reported non-zero R\&D expenditure in 1992. We chose 1992 as our sampling year because it was roughly the beginning of a period of rapid growth in R\&D spending in the United States. ${ }^{19}$ We focused on 2,215 firms from the six largest and most R\&D-intensive industries, with two-digit SIC of 28

\footnotetext{
${ }^{19}$ The median R\&D intensity (the ratio of R\&D expenditure to sales) for all Compustat firms with nonzero R\&D expenditure is $3.05 \%$ for 1992-1999, more than twice as high as the median of $1.37 \%$ for 1982-1991. Also the median annual growth in R\&D expenditure is $12 \%$ for $1992-1999$, compared to the median growth rate of 10\% for 1982-1991. The difference in the median R\&D intensity and annual growth of R\&D expenditure between these 1wo periods is statistically significant at the 0.001 level.
} 
(chemicals, biotech and pharmaceuticals), 35 (computer hardware and machinery), 36 (electrical and electronics), 37 (transportation equipment), 38 (medical and scientific instruments), and 73 (computer software and data services). ${ }^{20}$

Table 1

Summary of Sample Selection Procedure"

\begin{tabular}{lrr}
\hline Selection Criteria & Number & Percent \\
\hline Firms that reported non-zero R\&D expenditure in 1992 & 4.039 & $100 \%$ \\
Less: Firms not from the six R\&D-intensive industries & $-1,824$ & $-45.2 \%$ \\
Firms from the six R\&D-intensive industries & 2.215 & $54.8 \%$ \\
Less: Firms not covered on CRSP & -230 & $-5.7 \%$ \\
Firms covered on CRSP & 1.985 & $49.1 \%$ \\
Less: Firms with insufficient data on CRSP between 1987-1991 & -475 & $-11.8 \%$ \\
Firms covered on CRSP between I987-1991 & 1.510 & $37.4 \%$ \\
Final sample by random selection & 140 & $3.5 \%$
\end{tabular}

"Sample firms are selected from the 1999 Compustat merged files.

Table 2

Industry Composition of Sample Firms

\begin{tabular}{clrrrr}
\hline \multirow{2}{*}{ SIC } & Industry & & Final Sample & & Qualified Population \\
\cline { 5 - 5 } & Chemicals, biotech and pharmaceuticals & & Count (Percent) & & Count (Percent) \\
\hline 35 & Computer hardware and machinery & $30(21.4 \%)$ & & $294(19.5 \%)$ \\
36 & Electrical and electronics & $26(18.6 \%)$ & & $293(19.4 \%)$ \\
37 & Transportation equipment & $27(19.3 \%)$ & & $300(19.9 \%)$ \\
38 & Medical and scientific instruments & $7(5.0 \%)$ & & $76(5.0 \%)$ \\
73 & Computer software and data services & $30(21.4 \%)$ & & $320(21.2 \%)$ \\
Total & & $20(14.3 \%)$ & & $227(15.0 \%)$ \\
\hline
\end{tabular}

"Industry classification is based on two-digit SIC information.

We further required sample firms to have sufficient stock returns data that is needed to estimate beta. A total of 230 firms that were not covered by CRSP were deleted, leaving 1,985 firms for further selection. We chose the 1,510 firms that had stock return data for at least five years ( 60 months) before 1992. These firms were then divided into deciles based

20. In I992, R\&D expenditures from firms in the six industries account for about $81 \%$ of total R\&D expenditures of all Compustat firms. For the period 1982-1999, the median R\&D intensity for firms in these six industries is $7.48 \%$, compared to $1.44 \%$ for all other Compustat firms with non-zero R\&D expenditure, The difference is statistically significant at the 0.001 level. 
on R\&D intensity. From each decile, 14 companies were randomly selected, resulting in a final sample of 140 companies, or $9.27 \%$ of the 1.510 firms that met our criteria (hereinafter termed "the qualified population").

Table 2 reports the industry membership of the final sample in comparison with the qualified population. It shows that the six R\&D-intensive industries are similarly represented in the two groups, suggesting that our analysis should have sufficient control for cross-industry differences. The Pearson $\chi^{2}$ test fails to reject the null hypothesis that the two groups have the same industry composition at the 0.01 level.

In Table 3, we report summary statistics for the variables of interest along with other descriptive variables. Financial statement data were obtained from Compustat, and stock price and return data from CRSP. Data on equity registration and issuance were gathered from Investment Dealer's Digest (1992, 1993, 1994). Except for the disclosure score (DISC), all variables are as of the end of fiscal year 1992. To ascertain whether the final sample is representative of the population of firms engaged in R\&D-related innovation, the table also includes statistics for the qualified population of the 1,510 firms that met our data requirements. The mean and median differences between the two groups for each variable and their statistical significance levels are reported in the column titled "Difference".

Panel A of Table 3 shows that our final sample is similar to the qualified population with respect to factors that are expected to be associated with firms' disclosure about innovation. The null hypothesis that the value of these variables is the same for the two groups is not rejected at the 0.05 level (two-tailed) by either the $t$-test or Wilcoxon test. The last row of Panel A reports descriptive statistics on the disclosure score (DISC) for firms of the final sample for the period 1992-1994, computed according to the scoring procedure described in section 3. The mean value of DISC is 4,2, and the median is 2.0 . The standard deviation is 5.71 , indicating relatively large cross-sectional variation in the disclosure level among sample firms.

In Panel B, we report statistics for other measures of firm size and performance. Specifically, we measure firm size by sales (SALES) and total assets (ASSETS), For firm performance, we use return on equity $(R O E)$, operating margin $(O P M G)$, sales growth (SALESGW) and annual stock returns (RETURN). Again, none of the mean and median differences are significantly different from zero at the 0.05 level. The result thus confirms that the final sample is representative of the qualified population with respect to these firm characteristics. ${ }^{21}$

In our subsequent analysis, we examine the disclosure score based on press releases of sample firms for the period 1992-1994. Seven firms in the final sample did not survive beyond 1993. Among them, three firms ceased operation and four firms were acquired. Therefore, the estimation of equation (1) is based on 413 observations [ $(140 \times 3)-7]$, whereas 406 observations (413-7) are available for the regression of equations (3) to (5)..22

\footnotetext{
${ }^{21}$ To ensure that the similarity between the final sample and the qualified population is not due to chance, we performed 3,000 replications of our random sampling procedure. We found that with a total of 140 firms in the final sample, the relative frequency of observing statistically significant differences (at the 0.05 level) in the firm characteristics between the groups reported in Table 3 is less than $5 \%$.

${ }^{22}$ We also re-ran all regressions using data of the surviving firms only (399 observations) and found almost identical results.
} 
Table 3

Descriptive Statistics of Sample Firms

\begin{tabular}{|c|c|c|c|c|c|c|c|c|c|c|c|c|}
\hline \multirow[b]{2}{*}{ Variable } & \multicolumn{5}{|c|}{ Final Sample (140 Firms) } & \multicolumn{5}{|c|}{ Qualified Population (1,510 Firms) } & \multicolumn{2}{|c|}{ Difference } \\
\hline & Mean & $\begin{array}{l}\text { Standard } \\
\text { Deviation }\end{array}$ & $25 \%$ & Median & $75 \%$ & Mean & $\begin{array}{l}\text { Standard } \\
\text { Deviation }\end{array}$ & $25 \%$ & Median & $75 \%$ & Mean & Median \\
\hline \multicolumn{13}{|c|}{ Panel A: Variables of Interest } \\
\hline RDGW & 0.28 & 12.5 & $-0,02$ & 0.00 & 0.01 & 0.25 & 12.3 & -0.03 & 0.00 & 0.01 & 0.03 & 0.00 \\
\hline DLOSS & 0.38 & 0.48 & 0.00 & 0.00 & 1.00 & 0.39 & 0.49 & 0.00 & 0.00 & 1.00 & -0.01 & 0.00 \\
\hline RDINT & 0.29 & 0.87 & 0.02 & 0.06 & 0.13 & 0.28 & 0.85 & 0.02 & 0.06 & 0.13 & 0.01 & 0.00 \\
\hline AGE & 14.6 & 12.8 & 6.04 & 9.92 & 20.1 & 13.5 & 13.4 & 5.17 & 9.25 & 20.1 & 1.10 & 0.67 \\
\hline RETVOL & 0.18 & 0.09 & 0.10 & 0.15 & 0.21 & 0.17 & 0.11 & 0.10 & 0.14 & 0.21 & 0.01 & 0.01 \\
\hline $\operatorname{LOG}(\mathrm{RD})$ & 1.36 & 2.38 & -0.39 & 1.28 & 2.81 & 1.33 & 2.24 & -0.14 & 1.23 & 2.65 & 0.03 & 0.05 \\
\hline OFFER & 0.28 & 0.46 & 0.00 & 0.00 & 1.00 & 0.25 & 0.44 & 0,00 & 0.00 & 1.00 & 0.03 & 0.00 \\
\hline DIND & 0.14 & 0.35 & 0.00 & 0.00 & 0.00 & 0.12 & 0.33 & 0.00 & 0.00 & 0.00 & 0.02 & 0.00 \\
\hline $\mathrm{M} / \mathrm{B}$ & 3.63 & 6.34 & 1.27 & 2.14 & 3.85 & 3.71 & 11.41 & 1.16 & 2.07 & 3.81 & -0.08 & 0.07 \\
\hline LOG(MV) & 4.36 & 2.35 & 2.69 & 4.21 & 5.82 & 4.30 & 2.19 & 2.76 & 4.17 & 5.62 & 0.06 & 0.04 \\
\hline DISC & 4.21 & 5.71 & 0.00 & 2.00 & 6.00 & NA & $\mathrm{NA}$ & $\mathrm{NA}$ & NA & $\mathrm{NA}$ & NA & NA \\
\hline
\end{tabular}


Table 3 (cont.)

Descriptive Statistics of Sample Firms

\begin{tabular}{|c|c|c|c|c|c|c|c|c|c|c|c|c|}
\hline \multirow[b]{2}{*}{ Variable } & \multicolumn{5}{|c|}{ Final Sample (140 Firms) } & \multicolumn{5}{|c|}{ Qualified Population (1,510 Firms) } & \multicolumn{2}{|c|}{ Difference $^{b}$} \\
\hline & Mean & $\begin{array}{l}\text { Standard } \\
\text { Deviation }\end{array}$ & $25 \%$ & Median & $75 \%$ & Mean & $\begin{array}{l}\text { Standard } \\
\text { Deviation }\end{array}$ & $25 \%$ & Median & $75 \%$ & Mean & Median \\
\hline \multicolumn{13}{|c|}{ Panel B: Other Variables. } \\
\hline SALES & 918.8 & $2,919.4$ & 8.10 & 44.5 & 272.8 & $1,107.4$ & 5.767 .5 & 9.5 & 45.6 & 222.7 & -188.6 & -1.10 \\
\hline ASSETS & $1,042.4$ & $3,788.7$ & 10.40 & 41.1 & 288.2 & $1,308.3$ & 9.802 .8 & 11.4 & 45.1 & 186.6 & -265.9 & -4.00 \\
\hline ROE & -0.11 & 0.64 & -0.22 & 0.06 & 0.15 & -0.11 & 0.95 & -0.15 & 0.06 & 0.16 & 0.00 & 0.00 \\
\hline OPMG & 0.02 & 1.34 & 0.08 & 0,16 & 0.24 & 0.03 & 1.02 & 0.07 & 0.15 & 0.24 & -0.01 & 0.01 \\
\hline SALESGW & 0.20 & 0.10 & -0.05 & 0.10 & 0.24 & 0.17 & 0.07 & -0.05 & 0.07 & 0.23 & 0.03 & 0.03 \\
\hline RETURN & 0.14 & 0.72 & -0.23 & 0.04 & 0.42 & 0.11 & 0.68 & -0.30 & 0.03 & 0.49 & 0.03 & 0.01 \\
\hline
\end{tabular}

a Level variables are in millions of dollars. All variables are for the fiscal year 1992, except DISC

D. "Difference" is the difference in mean and median value between the final sample and total qualified population (the $t$-statistics and Wilcoxon rank-sum statistics for the statistical significance are in the parenthesis below the mean and median value, respectively).

Variables are defined as follows. RDGW is the change in R\&D intensity (the ratio of R\&D expenditure to sales) from year $t-3$ to year $t$. DLOSS is a dummy variable equal to 1 for firms reporting operating losses and 0 otherwise. RDINT is the R\&D intensity of year $t$. AGE is the number of years for which a firm is publicly traded. RETVOL is the volatility of monthly stock returns over the prior year. $L O G(R D)$ is the logarithm of R\&D expenditure of year $t$. OFFER is a dummy variable equal to I if the firm files a debt or equity registration statement in the current fiscal year or in the next two fiscal years, and 0 otherwise. DIND is a dummy variable equal to 1 for biotech and pharmaceutical firms (three-digit SIC of 283), and 0 otherwise, LOG(MV) is the logarithm of market value at fiscal year-end. M/B is the ratio of market value to book value. DISC is the score of firms' disclosure about innovation activities. SALES is total sales. ASSETS is total assets. ROE is return on equity (calculated by dividing net ineome by average of beginning and ending balances of shareholder equity). OPMG is operating margin, defined as operating income (before advertising expenses and R\&D expenditure) divided by sales. SALESGW is the sales growth rate. RETURN is annual stock return for the fiscal year. RDEXP is reported R\&D expenditure. 
Table 4

Pairwise Correlation Coefficient Between Disclosure Score and Firm Characteristics

\begin{tabular}{|c|c|c|c|c|c|c|c|c|c|c|c|}
\hline & DISC & RDGW & RDINT & DLOSS & AGE & RETVOL & LOG(RD) & OFFER & DIND & LOG(MV) & $\mathrm{M} / \mathrm{B}$ \\
\hline DISC & & 0.28 & 0.32 & 0.15 & -0.23 & 0.13 & 0.28 & 0.19 & 0.26 & 0.39 & 0.12 \\
\hline RDGW & 0.31 & & 0.17 & 0.11 & 0.15 & 0.04 & 0.09 & 0.03 & 0.10 & 0.04 & -0.05 \\
\hline RDINT & 0.47 & 0.16 & & 0.29 & -0.13 & 0.14 & 0.14 & 0.20 & 0.39 & 0.10 & 0.15 \\
\hline DLOSS & 0.09 & 0.12 & 0.34 & & -0.12 & 0.22 & $-0,08$ & -0.01 & 0.23 & -0.35 & 0.04 \\
\hline AGE & -0.19 & 0.12 & -0.24 & -0.14 & & -0.18 & -0.01 & -0.11 & -0.16 & 0.02 & 0.00 \\
\hline RETVOL & 0.11 & 0.01 & 0.19 & 0.21 & -0.23 & & -0.35 & -0.02 & 0.20 & -0.35 & -0.04 \\
\hline LOG(RD) & 0.34 & 0.13 & 0.36 & -0.09 & -0.01 & -0.33 & & 0.17 & 0.16 & 0.75 & 0.12 \\
\hline OFFER & 0.18 & -0.01 & 0.13 & -0.01 & -0.14 & -0.02 & 0.18 & & 0.16 & 0.23 & 0.12 \\
\hline DIND & 0.21 & 0.12 & 0.39 & 0.23 & -0.17 & 0.20 & 0.18 & 0.16 & & 0.20 & 0.17 \\
\hline LOG(MV) & 0.45 & -0.01 & 0.12 & -0.32 & -0.04 & -0.33 & 0.77 & 0.25 & 0.23 & & 0.16 \\
\hline $\mathrm{M} / \mathrm{B}$ & 0.28 & -0.03 & 0.20 & -0.05 & -0.09 & 0.08 & 0.18 & 0.16 & 0.28 & 0.36 & \\
\hline
\end{tabular}

Pearson (Spearman) correlation coefficients are reported above (below) the diagonal. Coefficients significantly different from zero at p-values less than $5 \%$ are in boldface type. DISC is the score of firms' disclosure about innovation activities. RDGW is the change in R\&D intensity (the ratio of R\&D expenditure to sales) from year $1-3$ to year $t$. DLOSS is a dummy variable equal to 1 for firms reporting operating losses, and 0 otherwise. RDINT is the R\&D intensity of year $t$. AGE is the number of years for which a firm is publicly traded. RETVOL is the volatility of monthly stock returns over the prior year. LOG(RD) is the logarithm of R\&D expenditure of year $t$. OFFER is a dummy variable equal to I if the firm files a debt or equity registration statement in the current fiscal year or in the next two fiscal years, and 0 otherwise. DIND is a dummy variable equal to I for biotech and pharmaceutical firms (three-digit SIC of 283), and 0 otherwise. LOG(MV) is the logarithm of market value at fiseal year-end. $\mathrm{M} / \mathrm{B}$ is the ratio of market value to book value. 


\subsection{Empirical analysis of Hypotheses 1 to 5}

Table 4 reports the Pearson and Spearman correlation coefficients between the disclosure level (DISC) and the independent variables of equation (1). It shows that disclosures are greater for firms with larger increases in $R \& D$ spending rate, firms with higher $R \& D$ intensity, firms reporting losses, younger firms, and firms with greater stock return volatility. At the univariate level, the direction of these associations is consistent with the predictions of Hypotheses 1 to 5. The associations between DISC and the control variables are as expected. The disclosure score is higher for firms accessing the capital market and firms from the biotech and pharmaceutical industries. We also find that disclosures increase with firm size and market-to-book ratios, which is consistent with prior studies (e.g. Tasker (1998), Lang and Lundholm (1993)).

Table 5 reports summary statistics from the multivariate regression of equation (1). The model is estimated by pooling observations from all three years. In unreported analysis, we also run separate regressions for each of the three years. We find that results based on the mean statistics of the annual regressions are similar to those reported in Table 5. In column (1), we report coefficient estimates when the dependent variable of the regression is the total disclosure score (DISC) summed across the three information categories described in section 3. Overall, it shows that the model explains a meaningful portion of the variation in the sample firms' disclosure level (37.3 per cent). As predicted, the coefficient on $R D G W$, the proxies for the lack of informativeness in current earnings, is positive and statistically significant at the 0.001 level (two-tailed), indicating that firms make greater disclosures of innovation when they experience higher increases in the R\&D spending rate. We also find that the coefficients on R\&D intensity (RDINT), the indicator of loss firms $(D L O S S)$, firm age $(A G E)$, and stock return volatility (RETVOL) all have the predicted signs and are statistically significant at the 0.01 level or better (two-tailed). These results are consistent with our prediction that firms make more disclosures of innovation when their future earnings are more uncertain.

The coefficient estimates for the control variables are primarily consistent with our predictions and with findings of prior studies. We find that disclosure levels are higher for firms with greater investment in R\&D activities. Consistent with firms' incentive to reduce cost of capital, we find that firms planning to access the capital market for debt or equity financing tend to disclose more news on innovation. The coefficient on firm size is positive and significant (at the 0.001 level), whereas the effect of market-to-book ratio is statistically insignificant. We also find that membership in the biotech and pharmaceutical industry is positively associated with disclosure level after controlling for other factors, although the coefficient is statistically insignificant.

In the remaining columns of Table 5 , we report summary statistics of regressions based on the disclosure score for each of the three information categories used in constructing the total disclosure score (DISC). Overall, the pattern of coefficient estimates is very similar to that based on the total disclosure score. After controlling for factors known to be associated with management disclosure decisions, the coefficients on the proxies for the lack of informativeness in earnings (RDGW) and uncertainty in future earnings (RDINT, DLOSS, $A G E$, and RETVOL) are found to have the predicted sign and they are statistically significant at the 0.05 level or higher, with the exception of RDINT in the regression for disclosure about completion. The results are stronger for disclosures about the strategy 
Table 5

Summary Statistics of Regression of Disclosure Score ( $t$-statistics in parentheses)

\begin{tabular}{|c|c|c|c|c|c|c|}
\hline \multicolumn{7}{|c|}{ 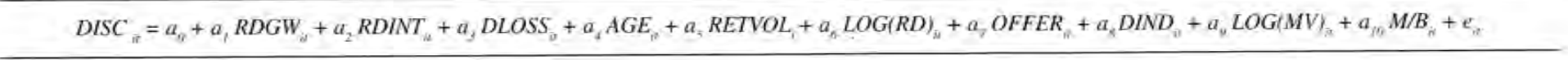 } \\
\hline \multirow[b]{2}{*}{$\begin{array}{l}\text { Independent } \\
\text { Variables }\end{array}$} & \multirow[b]{2}{*}{$\begin{array}{l}\text { Variable } \\
\text { Definition }\end{array}$} & \multirow[b]{2}{*}{$\begin{array}{l}\text { Expected } \\
\text { Sign }\end{array}$} & \multicolumn{4}{|c|}{ Dependent Variables } \\
\hline & & & $\begin{array}{c}\text { (1) Total } \\
\text { Disclosure (DISC) }\end{array}$ & $\begin{array}{l}\text { (2) Disclosure About } \\
\text { Strategy }\end{array}$ & $\begin{array}{l}\text { (3) Disclosure } \\
\text { About Progress }\end{array}$ & $\begin{array}{c}\text { (4) Disclosure } \\
\text { About Completion }\end{array}$ \\
\hline \multirow[t]{2}{*}{ Intercept } & Regression intercept & $?$ & -1.813 & -0.853 & -0.719 & 0.043 \\
\hline & & & $(-1.92)^{*}$ & $(-1.21)$ & $(-1.39)$ & $(0.08)$ \\
\hline \multirow{2}{*}{ RDGW } & Change in R\&D intensity & + & 0.167 & 0.114 & 0.115 & 0.012 \\
\hline & & & $(3.65)^{* * * *}$ & $(3.05)^{* * *}$ & $(4.29)^{* 5 *}$ & $(2.14)^{*}$ \\
\hline \multirow[t]{2}{*}{ RDINT } & R\&D intensity & + & 0.136 & 0.098 & 0.109 & 0.007 \\
\hline & & & $(2.51)^{* *}$ & $(2.58)^{* \%}$ & $(4.24)^{\text {रके }}$ & $(1.28)$ \\
\hline \multirow[t]{2}{*}{ DLOSS } & Dummy variable for loss firms & + & 1.367 & 0.791 & 0.768 & 0.691 \\
\hline & & & $(3.88)^{* * *}$ & $(2.82)^{* *}$ & $(3.29)^{* * *}$ & $(2.70)^{\text {क* }}$ \\
\hline \multirow[t]{2}{*}{ AGE } & Firm age & - & -0.059 & -0.037 & -0.018 & -0.038 \\
\hline & & & $(-2,84)^{* *}$ & $(-2.58)^{* *}$ & $(-1.92)^{*}$ & $(3.17)^{* * *}$ \\
\hline \multirow[t]{2}{*}{ RETVOL } & Stock return volatility & + & 3.397 & 4.595 & 2.297 & 2.221 \\
\hline & & & $(4.20)^{* * *}$ & $(3.57)^{* * 4}$ & $(2.29)^{*}$ & $(3.16)^{* * *}$ \\
\hline \multirow[t]{2}{*}{ LOG(RD) } & Logarithm of R\&D expenditure & + & 1.001 & 0.737 & 0.229 & 0.643 \\
\hline & & & $(5.12)^{* * *}$ & $(5.02)^{* * * 3}$ & $(2.13)^{*}$ & $(3.48)^{* * * *}$ \\
\hline \multirow[t]{2}{*}{ OFFER } & Dummy variable for firms & + & 1.666 & 0.753 & 0.976 & 0.219 \\
\hline & accessing the capital market & & $(2.79)^{* * *}$ & $(1.71)^{*}$ & $(2.81)^{* *}$ & (0.4I) \\
\hline \multirow[t]{2}{*}{ DIND } & Industry dummy & + & 0.019 & 0.006 & 1.362 & -0.583 \\
\hline & & & $(1.30)$ & $(1.38)$ & $(3.87)^{* * * *}$ & $(-2.18)^{*}$ \\
\hline
\end{tabular}


Table 5 (Cont.)

Summary Statistics of Regression of Disclosure Score ( $t$-statistics in parentheses)

\begin{tabular}{|c|c|c|c|c|c|c|}
\hline \multirow[b]{2}{*}{$\begin{array}{l}\text { Independent } \\
\text { Variables }\end{array}$} & \multirow[b]{2}{*}{$\begin{array}{l}\text { Variable } \\
\text { Definition }\end{array}$} & \multirow[b]{2}{*}{$\begin{array}{l}\text { Expected } \\
\text { Sign }\end{array}$} & \multicolumn{4}{|c|}{ Dependent Variables } \\
\hline & & & $\begin{array}{c}\text { (1) Total } \\
\text { Disclosure (DISC) }\end{array}$ & $\begin{array}{l}\text { (2) Disclosure About } \\
\text { Strategy }\end{array}$ & $\begin{array}{c}\text { (3) Disclosure } \\
\text { About Progress }\end{array}$ & $\begin{array}{c}\text { (4) Disclosure } \\
\text { About Completion }\end{array}$ \\
\hline \multirow[t]{2}{*}{ LOG(MV) } & Logarithm of market value & + & 0,649 & 0.583 & 0.259 & 0.227 \\
\hline & & & $(3,45)^{2 * * *}$ & $(3.39)^{* * *}$ & $(2.45)^{\text {*⿻一𠃋 }}$ & $(2.18)^{*}$ \\
\hline \multirow[t]{2}{*}{$\mathrm{M} / \mathrm{B}$} & Market-to-book ratio & + & 0.027 & 0.008 & 0.037 & -0.009 \\
\hline & & & $(1.59)$ & $(0.61)$ & $(2.87)^{* \varepsilon}$ & $(-0.83)$ \\
\hline Adjusted $\mathrm{R}^{2}$ & & & $37.3 \%$ & $29.9 \%$ & $41.7 \%$ & $12.4 \%$ \\
\hline
\end{tabular}

******* * indicates statistical significance at the $0.001,0.01$, and 0.05 level, respectively (two-tailed test).

DISC is the score of the firm's disclosure about innovation activities. RDGW is the change in R\&D intensity (the ratio of R\&D expenditure to sales) from year $t-3$ to year t. DLOSS is a dummy yariable equal to one for firms reporting operating losses and zero otherwise. RDINT is R\&D intensity in year $t$. AGE is the number of years for which a firm is publicly traded. RETVOL is the volatility of monthly stock returns over the prior year. LOG(RD) is the logarithm of R\&D expenditure. OFFER is a dummy variable equal to 1 if the firm files a debt or equity registration statement in the current fiscal year or in the next two fiscal years, and 0 otherwise. DIND is a dummy variable equal to 1 for biotech and pharmaceutical firms (three-digit SIC of 283), and 0 otherwise. LOG(MV) is the logarithm of market value at fiscal year-end. $\mathrm{M} / \mathrm{B}$ is the ratio of market value to book value. 
and progress of innovation than those about completion or commercialisation. Thus, the evidence in Table 5 provides consistent support to the predictions of Hypotheses 1 to 5 . We find that disclosure levels are higher when current earnings are less informative, or when future earnings are more uncertain. Overall, the evidence is consistent with hightechnology firms making more disclosures of innovation to meet greater investor demands for value relevant information.

Table 6

Market Response to Disclosures of Innovation by High-Technology Firms

\begin{tabular}{|c|c|c|c|c|c|}
\hline \multicolumn{6}{|c|}{ 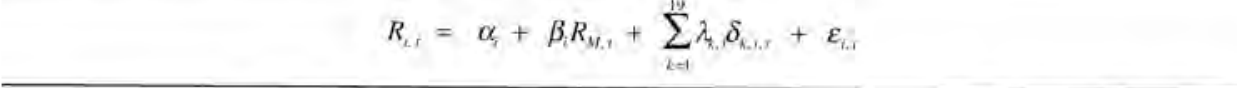 } \\
\hline \multirow[b]{2}{*}{$\begin{array}{l}\text { Independent } \\
\text { Variables }\end{array}$} & \multirow[b]{2}{*}{ Variable Definition } & \multicolumn{2}{|c|}{ Full Sample } & \multicolumn{2}{|c|}{ Restricted Sample " } \\
\hline & & $\begin{array}{l}\text { Coefficient } \\
\text { Estimates }\end{array}$ & $t$-statistics & $\begin{array}{c}\text { Coefficient } \\
\text { Estimates }\end{array}$ & $t$-statistics \\
\hline \multicolumn{6}{|c|}{ Panel A: Regression of Individual Disclosure Item } \\
\hline Intercept & Regression intercept & 0.001 & $6.81^{* * * * * 17}$ & 0.001 & $6.84^{* * * *}$ \\
\hline $\mathrm{R}_{\mathrm{M}}$ & Market return (value-weighted) & 0.821 & $21.5^{* * * *}$ & 0.816 & $21.3^{* * * *}$ \\
\hline$\delta_{1}$ & Discussion of strategy & 0.015 & $1.97 *$ & 0.014 & $1.92 *$ \\
\hline$\delta_{2}$ & Nature of innovation & 0.061 & $3.17 * * *$ & 0.066 & $3,33^{* * * * *}$ \\
\hline$\delta_{3}$ & Goal or objective of innovation & 0.001 & 0.14 & 0.002 & 0.18 \\
\hline$\delta_{4}$ & Relation with current innovation & -0.013 & -1.45 & -0.014 & -1.51 \\
\hline$\delta_{s}$ & Time frame & -0.009 & -0.53 & -0.014 & -0.73 \\
\hline$\delta_{6}$ & Amount of financing planned & 0.003 & 0.65 & 0.013 & $1.83^{*}$ \\
\hline$\delta_{q}$ & Form of R\&D venture & 0.016 & $2.72^{\text {k* }}$ & 0.016 & $2.58 * *$ \\
\hline$\delta_{x}$ & Acquisition of technology & 0.006 & 0.76 & 0.004 & 0.57 \\
\hline$\delta_{9}$ & Breakthrough of $R \& D$ & 0.029 & $7.57^{100 \% *}$ & 0.029 & $7.26^{* * * * * *}$ \\
\hline$\delta_{10}$ & Details of pipeline projects & -0.025 & $-1.96^{*}$ & -0.018 & $-1.78^{*}$ \\
\hline$\delta_{11}$ & Human capital & 0.006 & 0.37 & 0.004 & 0.24 \\
\hline$\delta_{12}$ & Implementation of projects & -0.005 & -0.46 & -0.003 & -0.23 \\
\hline$\delta_{1,}$ & Continuation of financing & -0.013 & -0.50 & -0.029 & -0.81 \\
\hline$\delta_{14}$ & Indication of project on schedule & 0.013 & 0.91 & 0.002 & 0.09 \\
\hline$\delta_{15}$ & New product launch & 0.015 & $3.62^{* * t+4 k}$ & 0.013 & 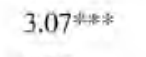 \\
\hline$\delta_{10}$ & Patent licensing and royalty & 0.012 & 0.98 & 0.012 & 0.98 \\
\hline$\delta_{17}$ & Transfer or sale of technology & 0.034 & $1,95^{*}$ & 0.038 & $1.98^{\%}$ \\
\hline$\delta_{i b}$ & Marketing alliance & 0.011 & 0.83 & 0.011 & 0.76 \\
\hline$\delta_{19}$ & Litigation & 0.011 & 0.94 & 0.019 & 1.56 \\
\hline Adj. $R^{2}$ & & $0.6 \%$ & & $0.6 \%$ & \\
\hline
\end{tabular}


Table 6 (Cont.)

Market Response to Disclosures of Innovation by High-Technology Firms

\begin{tabular}{|c|c|c|c|c|c|}
\hline \multirow[b]{3}{*}{$\begin{array}{l}\text { Independent } \\
\text { Variables }\end{array}$} & \multicolumn{3}{|c|}{ 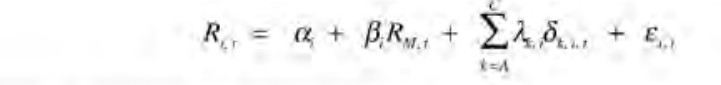 } & \multirow{2}{*}{\multicolumn{2}{|c|}{ Restricted Sample " }} \\
\hline & & Full S & nple & & \\
\hline & Variable Definition & $\begin{array}{r}\text { Coefficient } \\
\text { Estimates }\end{array}$ & $t$-statistics & $\begin{array}{r}\text { Coefficient } \\
\text { Estimates }\end{array}$ & $t$-statistics \\
\hline \multicolumn{6}{|c|}{ Panel B: Regression of Aggregate Disclosure Category } \\
\hline Intercept & & 0.001 & $6.8 \mathrm{I}^{\text {*kenk }}$ & 0.001 & $6.83^{\text {t }}$ \\
\hline $\mathrm{R}_{\mathrm{M} . i}$ & Market return (value-weighted) & 0.821 & $21.5^{\text {***** }}$ & 0.817 & $21,3 * * 4$ \\
\hline$\delta_{\Lambda}$ & Disclosure of strategy & 0.008 & $2.92^{* k *}$ & 0.013 & $3.73^{\text {tak }}$ \\
\hline$\delta_{\mathrm{B}}$ & Disclosure of progress & 0.022 & $6.66^{\text {*nat }}$ & 0,024 & $7.00^{* * * * *}$ \\
\hline$\delta_{c}$ & Disclosure of completion & 0.014 & $3.73^{\text {was }}$ & 0.012 & $3.13^{2 * * \text { * th }}$ \\
\hline Adj. $R^{2}$ & & $0.6 \%$ & & $0.6 \%$ & \\
\hline
\end{tabular}

a The "Restricted Sample" excludes disclosures made on earnings announcement dates,

t**, *olk, * indicates statistical signifieance at the $0.001,0.01$, and 0.1 level, respectively (two-tailed test).

$R_{i, i}$ is the firm's stock returns on day $t, R_{M, r}$ is the return on value-weighted market portfolio on day $t . \delta_{t, i}$ is the indicator variable for individual or aggregate disclosure types, which takes the value of -1 (1) if the firm disclosed information items containing negative (other news), and 0 otherwise, $k=1, \ldots 19$, or $k=\mathrm{A}, \mathrm{B}, \mathrm{C}$, where $k=1$ (articulation, explanation, and discussion of strategy), $k=2$ (nature of innovation), $k=3$ (goal, objective, or plan of innovation), $k=4$ (relation with current innovation), $k=5$ (time frame), $k=6$ (amount of financing or spending planned), $k=7$ (form of R\&D venture), $k=8$ (acquisition of other forms for new technology or other innovation capabilities), $k=9$ (breakthroughs or milestones of research and development). $k=10$ (details of pipeline projects or new products under development), $k=11$ (human capital), $k=12$ (implementation, continuatjon, or termination of R\&D projects), $k=13$ (continuation of available financing). $k=14$ (indication of whether R\&D projects are on schedule), $k=15$ (new product launch or acceptance by market), $k=16$ (patent licensing and royalty), $k=17$ (transfer or sale of technology or patent), $k=18$ (marketing alliance for new products), $k=19$ (litigation concerning intellectual properties), $k=\mathrm{A}$ (information about strategy relating to innovation), $k=\mathrm{B}$ (information about progress of innovation), $k=\mathrm{C}$ (information about completion or commercialisation of innovation).

\subsection{Empirical analysis of Hypotheses 6 and 7}

Table 6 reports estimates from the pooled regression of the conditional market model (equation (2)). Panel A reports that market responses are significantly positive to disclosures about the firm's strategy concerning innovation, form of R\&D venture, nature of innovation, breakthroughs of innovation, new product launches, and transfer or sale of the firm's technology. The evidence suggests that these disclosures convey price-sensitive news to the market. The coefficients for other disclosure types are statistically insignificant at conventional levels, except that the coefficient on details of pipeline projects has a negatively significant sign at the 0.10 level. Consistent with prior studies, the coefficient of market return on value-weighted portfolio is positive (0.821) and statistically significant at the 0.001 level. 
Panel B reports estimates of the conditional market model based on indicators of the three disclosure categories used in constructing the total disclosure score. The results show that market response to disclosures of strategy, progress, and completion concerning hightechnology firms' innovation is statistically significant at the 0.001 level, indicating, as expected, that on average these disclosures convey useful information to investors. As a robustness check, we also estimate the model after excluding a small number of disclosures made on earnings announcement dates to eliminate possible confounding effects (termed the "Restricted Sample" in Table 6). We find very similar results from this additional analysis.

Hypothesis 7 predicts that the disclosure level is positively related to the firm's future performance. In Table 7, we report the results from the regression of subsequent performance on current diselosure score DISC and control variables. In Panel A, the dependent variable of the regression is the sales growth rate of the next year (equation (3)). As expected, the coefficient estimates for all independent variables are positive and statistically significant at the 0.05 level or better (two-tailed tests). We find that firms with higher disclosure levels are associated with higher sales growth in the next year after controlling for the persistence of sales growth reflected by the coefficient on the lagged sales growth,

Table 7

Summary Statistics for the Regression of Subsequent Firm Performance on Current Disclosures About Innovation

\begin{tabular}{|c|c|c|c|c|}
\hline \multicolumn{5}{|c|}{$\operatorname{SALESG}_{i n+1}=b_{0}+b_{1}$ SALESG $_{i t}+b_{2}$ RDINT $_{n}+b_{3}$ CAPITAL $_{i t}+b_{7}$ DISC $_{n}+u_{i n}$} \\
\hline $\begin{array}{l}\text { Independent } \\
\text { Variable }\end{array}$ & Variable Definition & Expected Sign & $\begin{array}{l}\text { Coefficient } \\
\text { Estimates }\end{array}$ & $t$-statistics \\
\hline \multicolumn{5}{|c|}{ Panel A: Regression of Future Sales Growth (SALESGW ${ }_{1+1}$ ) } \\
\hline Intercept & Regression intercept & $?$ & 0.074 & $1.87 *$ \\
\hline SALESGW & Sales growth of year $t$ & + & 0.195 & $4.13^{\text {sok }}$ \\
\hline RDINT & $R \& D$ intensity & + & 0.052 & $11.4^{* k+k}$ \\
\hline CAPITAL & Dummy variable for new capital & + & 0.286 & $2.16^{*}$ \\
\hline DISC & Disclosure score & + & 0.164 & $2.63^{* * 8}$ \\
\hline Adjusted $\mathrm{R}^{2}$ & & & $34.6 \%$ & \\
\hline \multicolumn{5}{|c|}{$O P M G_{i n+1}=c_{\theta}+c_{i} O P M G_{i t}+c_{2} R D I N T_{i t}+c_{j} C A P I T A L_{i j}+c_{s} D I S C_{i t}+v_{i t}$} \\
\hline \multicolumn{5}{|c|}{ Panel B: Regression of Future Operating Margin (OPMG $\left.G_{t+1}\right)$} \\
\hline Intercept & Regression intercept & $?$ & 0.155 & $1.78^{*}$ \\
\hline OPMG & Operating income of year $t$ & + & 0.743 & $10,0^{\text {*a*k }}$ \\
\hline RDINT & $R \& D$ intensity & + & 0.057 & 2.81 政 \\
\hline C.APITAL & Dummy variable for new capital & + & 0.314 & $2,84^{* * *}$ \\
\hline DISC & Disclosure score & + & 0.117 & $2.88^{* * *}$ \\
\hline Adjusted $R^{2}$ & & & $38.8 \%$ & \\
\hline
\end{tabular}


Table 7 (Cont.)

Summary Statistics for the Regression of Subsequent Firm Performance on Current Disclosures About Innovation

\begin{tabular}{|c|c|c|c|c|}
\hline \multicolumn{5}{|c|}{ 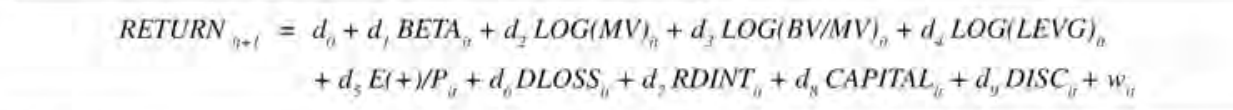 } \\
\hline $\begin{array}{l}\text { Independent } \\
\text { Variable }\end{array}$ & Variable Definition & Expected Sign & $\begin{array}{r}\text { Coefficient } \\
\text { Estimates }\end{array}$ & $t$-statistics \\
\hline \multicolumn{5}{|c|}{ Panel C: Regression of Future Stock Returns (RETURN } \\
\hline Intercept & Regression intercept & $?$ & 0.153 & 1.24 \\
\hline BETA & Firm beta & + & -0.034 & -0.88 \\
\hline LOG(MV) & Logarithm of market value & - & -0.015 & $-2.48^{* \neq 1 k}$ \\
\hline LOG(BV/MV) & Logarithm of book-to-market ratio & + & 0.029 & $3.96^{\text {*ik }}$ \\
\hline LOG(LEVG) & Logarithm of leverage ratio & + & 0.128 & $1.90^{*}$ \\
\hline$E(+) / P$ & Positive earnings & + & 0.092 & $2.04 *$ \\
\hline DLOSS & Dummy variable for loss firms & - & -0.068 & -0.60 \\
\hline RDINT & $R \& D$ intensity & + & 0.006 & 1.32 \\
\hline CAPITAL & Dummy variable for new capital & $?$ & 0.161 & 0.95 \\
\hline DISC & Disclosure score & + & 0.031 & $3.57^{\text {tonte }}$ \\
\hline Adjusted $\mathrm{R}^{2}$ & & & $2.7 \%$ & \\
\hline
\end{tabular}

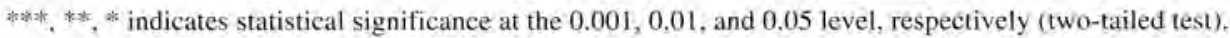
SALESGW is the sales growth rate. OPMG is operating margin, defined as operating income (before advertising expenses and R\&D expenditure) divided by sales. RDINT is R\&D intensity (the ratio of R\&D expenditure to sales). CAPITAL is a dummy variable equal to 1 if the firm accesses the capital market for debt or equity financing in the current fiscal year and 0 otherwise, RETURN is the firm's stock returns cumulated from nine months before the end of year $t+l$ to three month after it. BETA is the Capital Asset Pricing Model beta estimated using monthly stock returns over the preceding 60 months. LOG(MV) is the logarithm of market value at fiscal year-end. $\operatorname{LOG}(\mathrm{B} / \mathrm{M})$ is the logarithm of the ratio of book value of equity to market value (measured at fiscal year-end). LOG(LEVG) is the logarithm of financial leverage, calculated as the ratio of the book value of total assets to the book value of total equity. $\mathrm{E}(+) / \mathrm{P}$ is earnings before extraordinary items deflated by market value for firms with positive earnings and 0 for firms with negative earnings. DLOSS is a dummy variable equal to I for firms reporting operating losses and 0 otherwise. DISC is the score of the firm's disclosure about innovation activities.

benefits of investment in R\&D (RDINT), and availability of additional capital (CAPITAL). The coefficient on DISC is 0.164 (significant at the 0.01 level), indicating that, on average, the difference in sales growth rate between firms with a disclosure score of 1.0 and those with no useful disclosure is $16.4 \%$. The magnitude of the difference is thus economically meaningful and significant.

In Panel $\mathrm{B}$, we report the regression estimates of using operating margin (operating income before advertising and R\&D expenses divided by sales) as the performance measure (equation (4)). The pattern of coefficient estimates is similar to that reported in Panel A. All variables are positive and statistically significant at the 0.01 level or better. The coefficient on DISC is 0.117 , comparable to the value of 0.164 reported in Panel A. The 
magnitude of the coefficient estimate indicates that disclosures about innovation have economically significant associations with the future profitability of the firm.

Panel $C$ reports the results of estimating the Fama-French stock return model with the disclosure score included (equation (5)). Except for beta (BETA) and the dummy variable for loss firms (DLOSS), the risk factors have the predicted signs and are statistically significant at the 0.05 level or better. The coefficient estimates of RDINT and CAPITAL are positive but insignificant. The coefficient estimate of DISC is 0.031 (significant at the 0.001 level), indicating that, on average, an increase of 1.0 in the disclosure score is subsequently associated with an increase in risk-adjusted returns of $3.1 \%$. Thus, the magnitude of the association is economically significant. Similar to other findings of this type, the association may reflect a mis-pricing of securities, namely that investors under-react to disclosure of innovation, or an unidentified extra risk factor related to disclosure. Disentangling these alternative explanations involves a major endeavour and is obviously beyond the scope of our study. Regardless of the source of this association, the evidence enhances our conclusion that disclosures of innovation are predictive of high-technology firms' future economic performance.

\subsection{Sensitivity analysis}

Additional tests were performed to assess the robustness of our empirical results. Overall, these sensitivity tests do not change our main conclusions.

Alternative measures of disclosure level. We measure disclosure level by the number of press releases that contain non-redundant information about innovation as defined in section 3. Our analysis shows that the number of press releases is highly correlated with our disclosure score. ${ }^{23}$ We also rank firms in each two-digit SIC industry in each year by the disclosure score and use the value of the rank as a measure of disclosure level. When these two alternative measures of disclosure level are substituted for the raw disclosure score in the regression, we find that the regression estimates for all models are very similar and our conclusions concerning the main variables of interest are qualitatively unchanged.

Alternative measures of change in $R \& D$ spending rate. We also measure the change in the rate of $R \& D$ spending based on the pattern of $R \& D$ expenditure over a longer term by using a procedure similar to Lev and Zarowin (1999). Specifically, we replace our current measure $(R D G W)$ with a dummy variable that equals to one for firms with average $R \& D$ intensity below 0.1 from year $t-7$ to year $t-4$ and above 0.1 from year $t-3$ to year $t$, and zero otherwise. The purpose is to assess whether our current measure of change in the rate of $R \& D$ spending only captures temporary variation, namely the change from year $t-3$ to year $t$. When repeating the regression of equation (1), we find very similar results for this different measure of change in R\&D spending rate, whereas the coefficient estimates of other variables are unchanged.

Additional test of Hypothesis 7. To assess whether the association between disclosures of innovation and the firm's future performance is limited only to the next year, we extend the regression of equations (3) to (5) to performance measures of the subsequent two and three years, respectively. We find that the sign on the coefficient of the disclosure score

\footnotetext{
The Pearson (Spearman) correlation coefficient is $0.81(0.78)$, significant at the 0.001 level.
} 
$(D I S C)$ is consistently positive in all regressions and remains statistically significant in most regressions. The magnitude of the coefficient, however, is smaller when longer forecast horizons are examined. The result thus confirms our conclusion that disclosures of innovation are associated with the firm's future economic performance,

The influence of outliers. We deleted four observations with the value of the disclosure score (DISC) more than three times the standard deviation of the mean. When equation (1) is estimated without these four observations, we find that the coefficient estimates are relatively unaffected, but the statistical significance of most variables slightly increases. For regressions based on equations (3) to (5), removing these observations does not appear to have any material effect on the coefficient estimate of DISC. We also performed similar analysis for other variables, and our results are robust to the exclusion of observations with extreme values. ${ }^{34}$

\section{Summary and conclusions}

In this study, we investigate disclosure of innovative activities by high-technology firms. Our examination focuses on media disclosure of non-GAAP indicators that concerns the key elements of innovation, such as strategy, progress, and commercialisation. We base our analysis on a sample of 140 firms that are representative of companies that make substantial investments in technological innovation. Consistent with our predictions, we find that firms make greater disclosures of innovation when current earnings are less informative, or when future earnings are more uncertain. After controlling for factors known to be associated with management disclosure decisions, our results show that disclosures are greater for firms with larger increases in the rate of $R \& D$ spending, firms with higher R\&D intensity (the ratio of R\&D expenditure to sales), firms reporting losses, younger firms, and firms with more volatile stock returns. This evidence is consistent with firms making greater disclosures to accommodate investor information demands when financial accounting data are less useful, or when uncertainty about the firm's future earnings is higher.

We also find that disclosures of non-GAAP indicators relating to innovation convey price-sensitive news to the market. Moreover, we find that disclosures of innovation are positively associated with the firm's future economic performance. Our evidence suggests that management disclosure of innovation contains useful information. While prior research has shown a decline in the usefulness of earnings and other accounting information due to the increasing rate of innovation and inadequate accounting treatment of intangible assets, our findings suggest that firms are filling the gap with disclosure of non-GAAP indicators that are useful to investors.

\footnotetext{
${ }^{24}$ We computed diagnostic statistics suggested by Belsley et al. (1980) to assess whether our regression results are driven by outliers. Removing seven observations identified by this analysis as potentially influential does not change any of our inferences.
} 


\section{References}

Aboody, D. and B. Lev, 2000, "Information asymmetry, R\&D, and insider gains", Journal of Finance 55, $2747-2766$.

Belsley, D. E. Kuh and R. Welsch, 1980. Regression diagnostics (New York: John Wiley \& Sons, Inc.).

Botosan, C., 1997, "Disclosure level and the cost of equity capital". The Accounting Review 72, 323-349.

Bowen, R. and D. Shores, 2000, "Economic context and the value relevance of accounting data", Working Paper, University of Washington.

Campbell, J., A. Lo and A. MacKinlay, 1997, The econometrics of financial markets (Princeton, N.J.: Princeton University Press).

Chen, S., M. L. DeFond and C. W. Park. 2002, "Voluntary diselosure of balance sheet information in quarterly earnings announcements", Journal of Accounting and Economics 33, 229-251.

Clarkson, P., J. Kao and G. Richardson, 1994, "The voluntary inclusion of forecasts in the MD\&A section of annual reports", Contemporary Accounting Research 11, 423-450.

Cohen, L., 1992, "Some biotech firms excel at state-of-art hype". Wall Street Journal (March 13), C1.

Cohen, W., R. Nelson and J. Walsh, 2000, "Protecting their intellectual assets: Appropriability conditions and why U.S. manufacturing firms patent (or not)", Working Paper, Carnegie Mellon University.

Collins, D., E. Maydew and I. Weiss, 1997, "Changes in the value relevance of earnings and book values over the last forty years", Journal of Accounting and Economics 24, 39-67.

Darby, M., Q. Liu and L. Zucker, 1999, "Stakes and stars: The effect of intellectual human capital on the level and variability of high-tech firms' market values". Working Paper 7201, National Bureau of Economic Research.

Dye, R., 1985. "Disclosure of nonproprietary information", Journal of Accounting Research 23, 123-145.

Ely, K., P. Simko and L.G. Thomas, 2002, “The usefulness of biotechnology firms' drug development status in the evaluation of research and development costs", Working Paper, Georgia Institute of Technology.

Fama, E. and K. French, 1992, "The cross-section of expected stock returns". Journal of Finance 47, 427465.

FASB (Financial Accounting Standards Board), 2001 a, "Proposal for a new agenda project: Disclosure on information about intangible assets not recognized in financial statements".

FASB (Financial Accounting Standards Board), 2001b, "Improving business reporting: Insights into enhancing voluntary disclosures", Steering committee report, business reporting project.

Francis, J., D. Philbrick and K. Schipper, 1994, "Shareholder litigation and corporate disclosures", Journal of Accounting Research 32, 137-164.

Frankel, R.. M. McNichols and G. P. Wilson, 1995, "Discretionary disclosure and external financing", The Accounting Review 70, 135-150.

Grossman, S., 1981, "The informational role of warranties and the private disclosure about product quality", Journal of Law and Economics 24, 461-483.

Gu, F. and B. Lev, 2002, "On the relevance and reliability of R\&D", Working Paper, New York University.

Harris, M., 1998. "The association between competition and manager's business segment reporting choices", Journal of Accounting Research 36, 111-128.

Hayn, C., 1995, "The information content of losses", Journal of Accounting and Economics 20, 125-153.

Healy, P., A. Hutton and K. Palepu, 1999, "Stock performance and intermediation changes surrounding sustained increases in disclosure*", Contemporary Accounting Research 16(3), 485-520.

International Accounting Standards Committee (IASC), 1998, "Intangible assets", International Accounting Standards No. 38, London.

Jones, C. and S. Weingram, 1996, "The determinants of 106-5 litigation risk", Working Paper, Stanford University. 
King, R., G. Pownall and G. Waymire, 1990, "Expectations adjustment via timely management forecasts: Review, synthesis and suggestions for future research", Journal of Accounting Literante 9, 113-144.

Kothari, S. P., T. Laguerre and A. Leone, 2002, "Capitalization versus expensing: Evidence on the uncertainty of future earnings from capital expenditures versus R\&D outlays", Review of Accoumting Studies 7(4), $355-382$.

Lang, M., 1991, "Time-varying stock price response to earnings induced by uncertainty about the time-series process of earnings". Journal of Accounting Research 29, 229-257.

Lang, M. and R. Lundholm, 1993, "Cross-sectional determinants of analyst ratings of corporate disclosure", Journal of Accounting Research 31, 246-27I.

Lev, B., 2001, Intangibles: management, measurement, and reporting (Washington, D. C, Brookings Institution Press).

Lev, B. and P. Zarowin, 1999, "The boundaries of financial reporting and how to extend them", Journal of Accounting Research (Supplement) 37, 353-385.

Levin, R., A. Klevorick, R. Nelson and S. Winter, 1987, "Appropriating the returns from industrial R\&D". Brookings Papers on Economic Activity, 783-820.

Lundholm, R. and L. Myers, 2002, "Bringing the future forward: The effect of disclosure on the returnsearnings relation". Journal of Accounting Research 40, 809-839.

Mansfield, E. and S. Wagner, 1977. The production and application of new industrial technology (New York. N.Y.: Norton).

Securities and Exchange Commission (SEC), 2001. "Strengthening financial markets: Do investors have the information they need?". report by the SEC-Inspired Task Force.

Sengupta. P, 1998, "Corporate disclosure quality and the cost of debt". The Accounting Review 73, 459-474.

Shortridge, R., 2000, "Measuring R\&D success: A study of new drug approvals in the pharmaceutical industry". Working Paper, Ball State University.

Skinner, D.. 1994, "Why firms voluntarily disclose bad news?", Journal of Accounting Research 32, 38-60.

Tasker, S., 1998. "Bridging the information gap: Quarterly conference calls as a medium for voluntary disclosure", Review of Accounting Studies 3, 137-167.

Verrecchia, R., 1983, "Discretionary disclosure", Jounal of Accounting and Economics 32, 97-108.

Watts, R. and R. Leftwich, 1977, "The time series of annual accounting earnings", Iournal of Accounting Research 15, 253-271. 